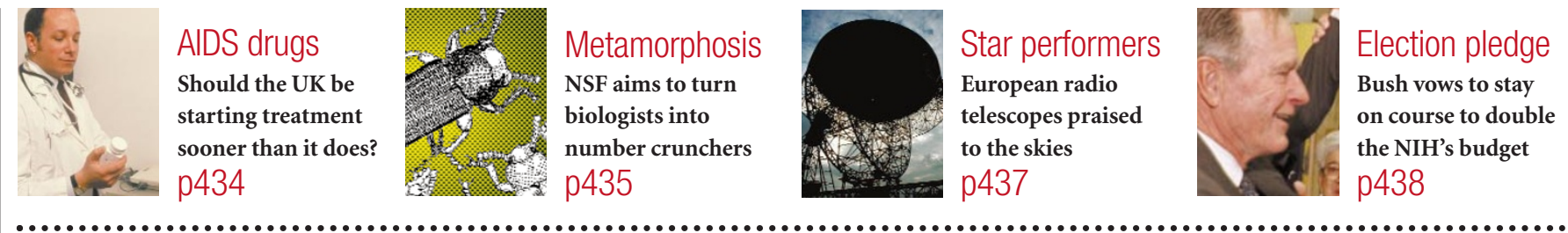

\title{
Europe urged to set up advisory body on research infrastructure
}

Quirin Schiermeier, Munich

A coordinated approach to scientific infrastructure across Europe came a step closer last week, when a high-level meeting in Strasbourg endorsed a proposal to set up a permanent body to advise the European Commission on such a strategy.

The body would be made up of science administrators from member states of the European Union (EU) and representatives of the commission. It had been proposed by the steering committee of a conference held in Strasbourg on the funding and maintenance of European research infrastructures.

Keen to speed up the planning and implementation of joint facilities, several speakers at the meeting also suggested that the European Science Foundation (ESF) should assess and advise on ways of matching infrastructure needs and resources in the EU.

Such needs include electronic communi-

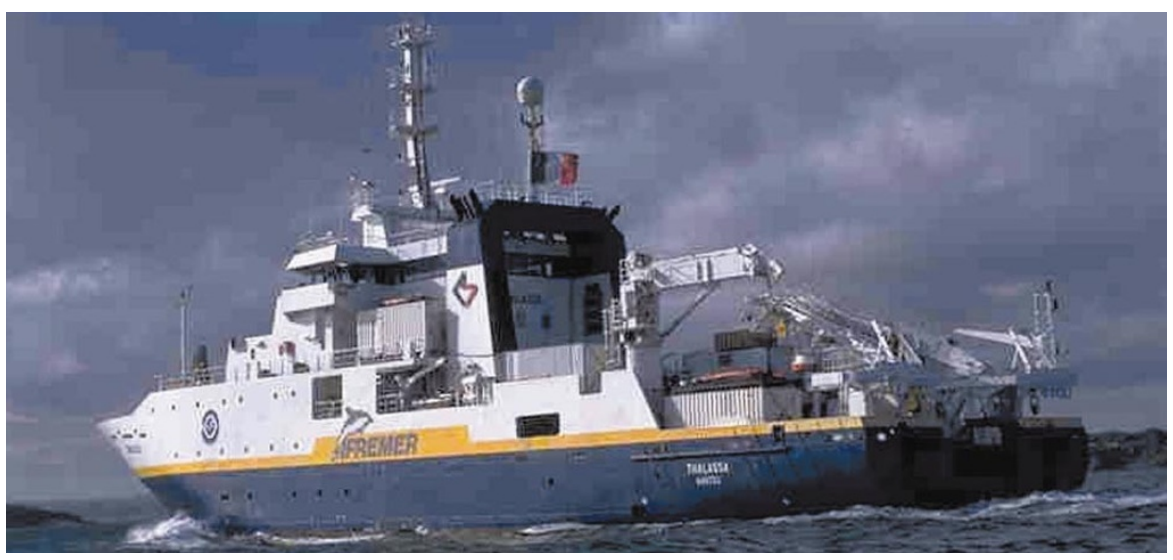

All aboard: research vessels are one area where a coordinated European policy is needed.

cation networks, databases for the natural and social sciences, telescopes, synchrotron radiation machines, research vessels, and centres in animal and plant physiology.

\section{Canadian science told to look north}

David Spurgeon, Montreal

Canada should rebuild its flagging research programme into northern regions to meet the challenges posed by climate change, rapid population growth, pollution, and social, health and education issues, according to a national task force.

The task force was set up by the country's Natural Sciences and Engineering Research Council (NSERC) and the Social Sciences and Humanities Research Council. Its findings were released last week at the American Association for the Advancement of Science's 51st Arctic Science Conference in Whitehorse, Yukon.

"We have agreed to explore ways of funding parts of it from our existing budgets," said Tom Brzustowski, NSERC's president. "But full implementation will require substantial new funding from the federal government."

In recent years Canada has withdrawn from northern research because of a shortage of funds. "We no longer have the effective research presence in the north that we need to help safeguard this unique and sensitive environment," says the task force's chairman, Tom Hutchinson of Trent University, Peterborough, Ontario.

The task force had 17 members from university, government and northern communities whose expertise covered natural and social sciences and engineering.

Its report proposes a programme that would establish 14 university chairs in northern research, create 40 northern graduate scholarships and 40 postdoctoral fellowships, support 70 strategic research projects, build partnerships between communities and researchers, and provide money for equipment and infrastructure.

"These measures will allow us to interest young researchers in the north, make sound policy decisions on northern issues, meet major international commitments in the circumpolar region and reassert Canadian sovereignty in the north," says Hutchinson. http://www.nserc.ca/media_e.htm
At present, setting up multinational research facilities under the auspices of the EU requires multilateral — and often cumbersome - agreements between all member states. Many European scientists and science organizations complain that this delays funding decisions relative to the United States and Japan. Science administrators, particularly in the smaller European countries, also complain that it is difficult to get their voice heard in planning new facilities.

"We keep hawking about our plans for a new medium-scale European neutron source," Raoul Kneucker, director-general of the Austrian science ministry, told the meeting. "But obviously there is no relevant panel in the EU where we could go to."

Speakers in Strasbourg suggested that a permanent strategic body could fill the hole. Its role, they said, would be to pave the way for scientific needs to become political funding decisions, in collaboration with the commission and EU member states.

"This would give stability and continuity to the process [and] facilitate a network of decision-makers and funders and hopefully increase the speed of the decision making process," the meeting's steering committee concluded in a formal proposal.

The Strasbourg meeting was organized by the European Commission and the ESF. Senior ESF officials helped to draft the recommendations that were endorsed, including the proposal to set up an advisory group. 
Philippe Busquin, the research commissioner, backs the idea of such a group. "A network of pan-European research infrastructures can become a major component of the European Research Area," Busquin told Nature (see Nature 405, 873; 2000). "I am happy about the high level of agreement reached at this important meeting."

Busquin says that he also welcomes the steering group's recommendation

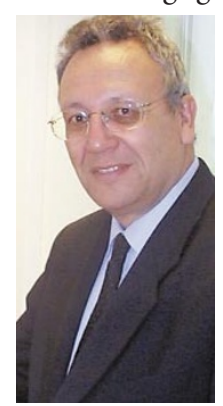
that the commission increase its financial support for building and running common research facilities and giving scientists access to them.

This would be good news for two European life-science facilities, the European Busquin: backs Mouse Mutant Archive proposed panel. (EMMA) near Rome and the European Bioinformatics Institute (EBI) near Cambridge. Both are in financial difficulties because the rules of the EU's current Fifth Framework Programme exclude such costs from funding.

"The Sixth Framework Programme [FP6], starting in 2003, will certainly contain elements which will help solve the problems of facilities such as EMMA and EBI," predicts Busquin.

Indeed, a proposal to increase infrastructure funding reflects the commission's intention to revise its whole approach under FP6. According to one official, the commission proposes to give less money to small, scattered projects which are often of questionable effectiveness (see Nature 404, 695; 2000). The money freed up could then be spent on infrastructure, he says.

"But the commission's role in the funding of infrastructure can only be that of a minority partner, who can hopefully catalyse initiatives," says Busquin, adding that the commission has neither the money nor the power to set up large research facilities without support from member states.

Speaking at last week's meeting, government representatives welcomed proposals to make greater use of the 'variable geometry' approach, under which countries can choose whether to participate in funding particular research facilities.

But an official from the German research ministry points out that governments' enthusiasm for collaboration on research infrastructure is likely to vanish if the costs of new facilities exceed the benefits to the national science base.

http://www.cordis.lu/improving/src/

ari_conf_res_infr.htm

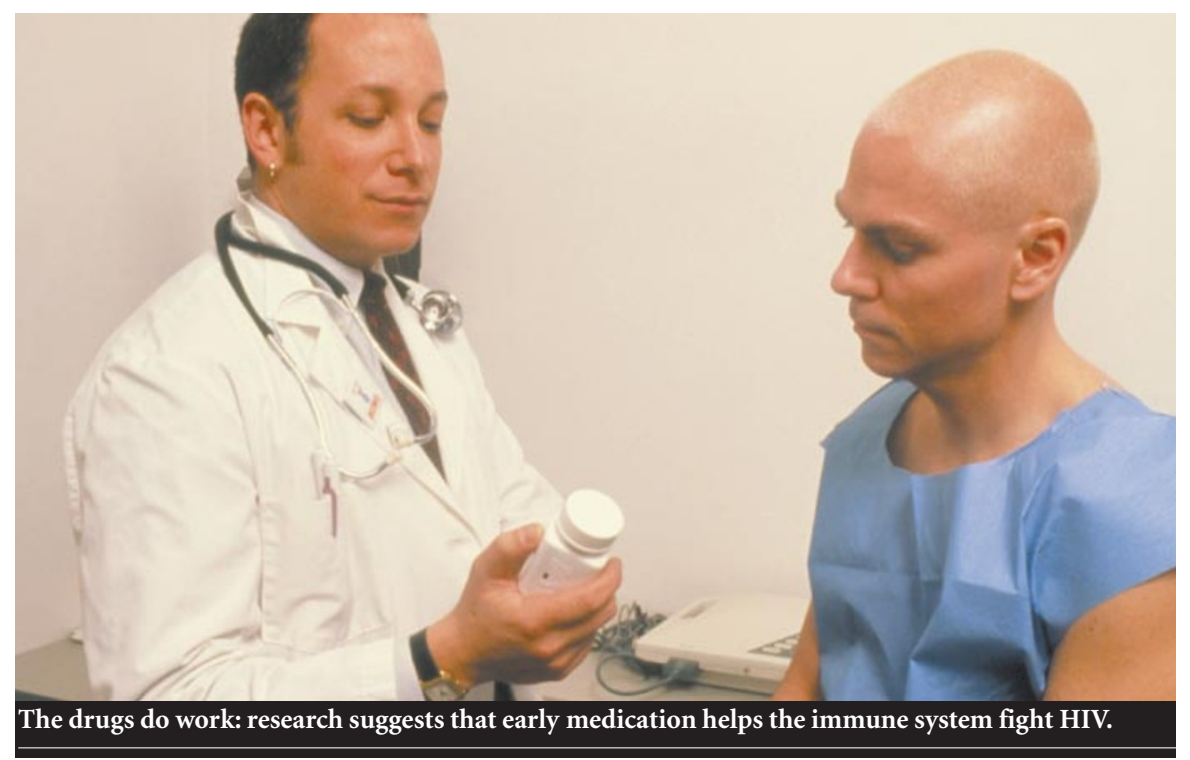

\section{UK faces rethink on AIDS treatment}

\section{Karen Birmingham, London}

Britain might have to reassess its policy for treating AIDS in the light of new results published this week.

Research at Massachusetts General Hospital and Harvard Medical School in Boston suggests that starting aggressive drug therapy as soon as HIV infection is confirmed is the most effective way to combat the virus. This strategy, say the researchers, allows the patient to develop specialized immune cells that attack the virus (see page 523).

Unlike the United States and most of Europe, Britain delays such treatment until the number of $\mathrm{CD} 4$ cells - white blood cells involved in the immune response - drops to below 350 cells per cubic millimetre. This can take several years after initial infection.

The study looked at patients who began taking a cocktail of drugs known as highly active antiretroviral therapy (HAART) within 180 days of infection with HIV. The treatment increased levels of specialized CD4 cells that can destroy HIV-infected cells, and the patients were able to stop taking the medication for up to a year and still suppress HIV levels in their blood. Patients who did not start on HAART until their infection had become 'chronic' showed no signs of this effect.

The case for early treatment is now compelling, says Bruce Walker, director of the Partners AIDS Research Center at Massachusetts General Hospital and one of the paper's co-authors. He is calling for tests that can detect the acute stages of HIV infection to be licensed by the US Food and Drug Administration. This would allow diagnosis roughly two weeks earlier than is possible using current tests.

But Walker and his colleagues stress that their results do not mean that patients can stop taking their medication without supervision. "It is the drugs that help the immune system to generate the correct CD4 cells," Walker says. "More fine tuning is needed to know how long you need to treat people before you [can] interrupt therapy, and how long that interruption [can] last."

Mike Saag, an AIDS researcher at the University of Alabama at Birmingham, says that the results establish 'proof of principle' that HIV-specific CD4 cells are critical to the body's ability to fight the disease.

"This CD4 cell help is lost very early in the course of infection - within 6 to 12 weeks - and the implication is that early use of antiretrovirals helps preserve this function," he says. "Once preserved, it seems to perpetuate itself even after antiretroviral therapy is stopped for up to a year."

The success of HAART drugs has led to a dramatic fall in AIDS mortality in the western world, but Britain has resisted giving otherwise healthy people these powerful drugs. Over the past two years, as toxic side effects of the long-term use of HAART have surfaced, such caution has seemed justified. Patients can suffer disfiguring body-fat redistribution that might be associated with diabetes and cardiovascular diseases.

Although the new data suggest that immediate treatment could reduce the time that patients spend on the drugs, Jonathan Weber, professor of communicable diseases at Imperial College School of Medicine in London, and a proponent of delaying therapy, urges caution.

"HIV is a long illness, and just because someone looks great at two years, it doesn't tell you what will happen 14 years later," he says. But he admits that "the time is right to start a randomized clinical trial of when it is best to start treatment." 